\title{
Pengaruh Label Halal, Kesadaran Halal, Iklan, dan Celebrity Endorser terhadap Minat Pembelian kosmetik melalui variabel Persepsi sebagai mediasi \\ (Studi Pada Civitas Akademika Universitas Muhammadiyah Ponorogo)
}

\author{
Premi Wahyu Widyaningrum \\ Fakultas Ekonomi, Universitas Muhammadiyah Ponorogo, Indonesia \\ E-mail : premi.wahyu@gmail.com
}

\begin{abstract}
Halalness is the main point for Muslims to worship so that people are always on the right path, besides that the halal is stated in the hadith and Al-Quran. Likewise with the interest of consumers trying cosmetics, because cosmetics have shifted from complement to necessity for some groups. Not infrequently, cosmetics are a primary need for monthly shopping. Products that have religious elements, such as cosmetics with halal labels and religious imagery, of course, require celebrities who have a personal and good impression of Muslim women. This will give a positive perception on the minds of consumers then it will cause stimuli to give interest in buying the product. The purpose of this study is to measure how much consumers are aware of consuming halal products, especially the academic community of Muhammadiyah Ponorogo University. This research was conducted at the Muhammadiyah Ponorogo University with a population of academics who are consumers of halal cosmetics. The research location is right on Jl. Budi Utomo no 10 Ponorogo. The sampling technique used a systematic random sampling method, with a sample size of 100 people. The data obtained will be analyzed using the GSCA analysis tool. The results showed that the use of Halal Labels, Halal Awareness, Advertising, and Celebrity Endroser appropriately, effectively and efficiently would provide a large stimulus to Consumer Perceptions in Purchase Intention.
\end{abstract}

Keyword: Halal Awareness, Advertising, Celebrity Endroser, Perceptions, Purchase Intention

\begin{abstract}
Abstrak
Kehalalan merupakan pokok utama bagi umat muslim untuk beribadah agar senantiasa manusia selalu di jalan yang benar, disamping itu kehalalan tertera dalam hadist dan Al-Quran. Demikian juga dengan minat konsumen mencoba kosmetik, karena kosmetik telah bergeser dari pelengkap menjadi kebutuhan bagi sebagian kalangan. Tidak jarang, kosmetik menjadi kebutuhan primer dalam belanja bulanan. Produk yang memiliki unsur religious, seperti kosmetik dengan label halal dan citra religious tentu saja membutuhkan selebriti yang memiliki personal dan kesan muslimah yang baik. Hal ini akan memberikan persepsi yang positif pada benak konsumen kemudian akan menimbulkan stimuli untuk memberikan minat pembelian pada produk tersebut. Tujuan dari penelitian ini yakni ingin mengukur seberapa besar kesadaran konsumen mengkonsumsi produk halal, khususnya civitas akademik Universitas Muhammadiyah Ponorogo. Penelitian ini dilakukan di lingkungan Universitas Muhammadiyah Ponorogo dengan populasi civitas akademika yang merupakan konsumen kosmetik halal. Lokasi penelitian berada tepat di Jl. Budi Utomo no 10 Ponorogo. Teknik pengambilan sampel menggunakan metode systematic random sampling, dengan jumlah sampel 100 orang. Data yang diperoleh akan dianalisa menggunakan alat analisis GSCA. Hasil penelitian menunjukkan bahwa penggunaan Label Halal, Kesadaran Halal, Iklan, dan Celebrity Endroser secara tepat, efektif dan efisien akan memberikan stimulus yang besar pada Persepsi konsumen dalam Minat Pembelian.
\end{abstract}

Kata kunci : Kesadaran Halal, Iklan, Celebrity Endroser, Persepsi, Minat Pembelian 


\section{JURNAL EKONOMI DAN MANAJEMEN \\ P-ISSN: 2598-9022/ E-ISSN: 2598-9618 \\ Available at:}

http://e-journal.unipma.ac.id/index.php/capital

\section{A. PENDAhuluan}

Kehalalan akan menjadi penting dalam kajian pemasaran di Indonesia, karena saat ini konsumen akan memperhatikan label halal yang tertera pada produk yang diperjualbelikan pada pasar. Umat muslim percaya bahwa dengan mengkonsumsi makanan yang halal akan menjadi berkah dan sehat untuk manusia, hal ini merupakan salah satu indikator dari kesadaran halal pada konsumen. Islam mengajarkan kita agar senantiasa untuk mengkonsumsi yang ada dimuka bumi yang serba halal dan baik, baik makanan dan minuman bahkan selain itu seperti kosmetik, obat-obatan dan lainlainnya. Kosmetik dan obat-obatan keduanya disebut halal apabila bahanbahan yang terkandung dalam keduanya harus dari bahan baku pilihan yang sesuai syariat islam dan memiliki sertifikat halal dari Majelis Ulama Indonesia.

Menurut Sumarwan (2011, h.209) konsumen Islam cenderung memilih produk yang dinyatakan halal dibandingkan dengan produk yang belum dinyatakan halal oleh lembaga berwenang. Demikian juga dengan minat konsumen mencoba kosmetik, karena kosmetik telah bergeser dari pelengkap menjadi kebutuhan bagi sebagian kalangan. Wanita cenderung membelanjakan uangnya lebih banyak untuk penampilan seperti pakaian, alat-alat perawatan, kecantikan rambut dan sebagainya (Kasali,1998:34). Didukung oleh pendapat Belch \& Belch (2001,h.159), kosmetik adalah salah satu pembelian yang menekankan keterlibatan perasaan (emosional), sehingga terkadang figur atau tokoh idola yang menjadi brand ambassador pada suatu iklan kosmetik dapat menstimulan pembelian.

Pemilihan selebriti dalam penyampaian pesan tersebut nantinya diharapkan dapat menimbulkan dampak yang cepat dalam brand awareness dan brand recognition. Ketepatan memilih sumber pesan (Endorser) dapat didasarkan pada atribut yang melekat pada Endorser tersebut (Shimp, 2003: 460). Penggunaan komunikator celebrity endorser yang memiliki karakteristik akan dapat mempengaruhi persepsi atau tanggapan konsumen yang 


\section{JURNAL EKONOMI DAN MANAJEMEN \\ P-ISSN: 2598-9022/ E-ISSN: 2598-9618 \\ Available at:}

http://e-journal.unipma.ac.id/index.php/capital

positif terhadap produk tersebut, sehingga konsumen akan mempertimbangkannya dalam proses pembe-lian dan diharapkan secara langsung mempengaruhi perilaku melalui alam bawah sadar. Dalam hal ini beberapa kosmetik halal yang menjadi obyek penelitian menggunakan beberapa selebriti yang memiliki kesan religius seperti Dewi Sandra, Inneke Koesherawati, Alyssa Soebandono, Lisa Namuri dan Dian Pelangi (Momzhak, 2015).

Faktor resiko yang tinggi seringkali dikalahkan oleh tampilan iklan, Apalagi iklan produk-produk kosmetik yang ditawarkan, terlihat begitu menjanjikan suatu perubahan penampilan. Natalia \& Pramadi dalam Pertiwi (2009:6) menyatakan bahwa kosmetik merupakan sarana yang digunakan wanita untuk mewujudkan bayangan dirinya seperti yang diinginkannya. Churchill dalam Pertiwi (2009:6), mengatakan bahwa wanita mempunyai kebiasaan mendengar atau membaca iklan, sehingga wanita lebih mudah dipengaruhi oleh iklan dan pada akhirnya akan mudah juga dipengaruhi minat membelinya. Shimp (2003:374) menyatakan iklan dapat mempengaruhi pengharapan konsumen tentang suatu produk, dan menggerakkan untuk melakukan pembelian.

Menurut Peter \& Olson (2000,h.92) yang mendefinisikan minat beli sebagai kecenderungan konsumen untuk membeli suatu merek atau mengambil tindakan yang berhubungan dengan pembelian yang diukur dengan tingkat kemungkinan konsumen melakukan pembelian. Minat beli dipengaruhi oleh dua faktor yakni faktor internal dan faktor eksternal. Internal diri konsumen, yang berupa motivasi, persepsi, perasaan dan emosinya merupakan faktor internal. Sedangkan, hal-hal usaha pemasaran dan faktor sosial budaya merupakan faktor eksternal.

Iklan di televisi didominasi oleh iklan barang untuk dikonsumsi, tak terkecuali produk kosmetik. Saat ini banyak iklan kosmetik yang mengklaim produknya sebagai kosmetik halal. Salah satu merek kosmetik halal yang memiliki image yang kuat kosmetik halal, mendapatkan penghargaan dari Indonesia International Halal Expo 


\section{JURNAL EKONOMI DAN MANAJEMEN \\ P-ISSN: 2598-9022/ E-ISSN: 2598-9618 \\ Available at:}

http://e-journal.unipma.ac.id/index.php/capital

(INDHEX) dalam kategori iklan halal terbaik tahun 2016 dari LPPOM MUI (Budiawati. 2016). Kategori ini dinilai berdasarkan program sosialisasi dan promosinya menempatkan aspek halal sebagai selling point. Strategi komunikasi dan promosi produk kosmetik halal secara lugas juga mudah ditangkap oleh publik sebagai kosmetik yang memiliki kandungan dan diproses secara halal.

Peranan celebrity endroser sebagai "wajah" dari produk halal tersebut memberikan dampak dalam mengkomuni-kasikan merek tersebut, sedangkan persepsi kosmetik halal pada benak konsumen merupakan stimuli yang tepat untuk menimbulkan minat pembelian. Pemasar dengan menciptakan label halal, kesadaran halal, iklan, celebrity endroser dan membuat konsumen mempersepsikan kebutuhannya akan produk, menggerakkan minat mereka pada produk dan melakukan tindakan pembelian (Shimp; 2003:385).

Peneliti mengambil obyek penelitian pada konsumen Civitas Akademik Universitas Muhammadiyah Ponorogo karena ingin melihat kesadaran mengkonsumsi produk halal dalam kehidupan sehari-harinya. Pendidikan mengenai agama islam yang dilakukan oleh Syarikat Muhammadiyah pada Civitas Akademika Universitas Muhammadiyah Ponorogo akan dapat diukur keberhasilannya pada aspek implementasi nilai-nilai islam dalam kehidupan sehari-hari, khususnya melalui perilaku pembelian produknya.

Berdasarkan latar belakang masalah di atas dan untuk memperjelas pokok pembahasan pada penelitian ini, maka masalah dalam penelitian ini dapat dirumuskan sebagai berikut:

1) Apakah Label Halal berpengaruh terhadap Persepsi?

2) Apakah Kesadaran Halal berpengaruh terhadap Persepsi?

3) Apakah Iklan berpengaruh terhadap Persepsi?

4) Apakah Celebrity Endorser berpengaruh terhadap Persepsi?

5) Apakah Label Halal berpengaruh terhadap Minat Pembelian?

6) Apakah Kesadaran Halal berpengaruh terhadap Minat Pembelian? 


\section{JURNAL EKONOMI DAN MANAJEMEN \\ P-ISSN: 2598-9022/ E-ISSN: 2598-9618 \\ Available at:}

http://e-journal.unipma.ac.id/index.php/capital

7) Apakah Iklan berpengaruh terhadap Minat Pembelian?

8) Apakah Celebrity Endorser berpengaruh terhadap Minat Pembelian?

9) Apakah Persepsi berpengaruh terhadap Minat Pembelian?

\section{B. TINJAUAN PUSTAKA}

\section{Definisi label halal menurut berbagai literatur}

Kata halal ( حلال, halāl, halaal) adalah istilah bahasa Arab dalam agama Islam yang berarti diizinkan" atau "boleh". Secara etimologi, halal berarti hal-hal yang boleh dan dapat dilakukan karena bebas atau tidak terikat dengan ketentuan-ketentuan yang melarangnya. Menurut Qardawi (2007, h.5) Istilah halal dalam kehidupan sehari-hari sering digunakan untuk makanan ataupun minuman yang diperolehkan untuk dikonsumsi menurut syariat Islam. Sedangkan dalam konteks luas istilah halal merujuk kepada segala sesuatu baik itu tingkah laku, aktifitas, maupun cara berpakaian dan lain sebagainya yang diperbolehkan atau diizinkan oleh hukum Islam.
Label halal merupakan pencantuman tulisan atau pernyataan halal pada kemasan produk untuk menunjukkan bahwa produk yang dimaksud berstatus sebagai produk halal. Label halal diperoleh setelah mendapatkan sertifikat halal. Sertifikat halal ini merupakan syarat untuk mendapatkan ijin pencantuman label halal pada kemasan produk dari instansi pemerintah yang berwenang. Adapun yang dimaksud dengan produk halal adalah produk yang memenuhi syarat kehalalan sesuai dengan syariat Islam.

Produk kosmetik memang tidak dimakan dan masuk ke dalam tubuh.Oleh karena itu kosmetik biasanya dikaitkan dengan masalah suci atau najis.Produk tersebut bisa dikatakan haram jika produk kosmetik tersebut mengandung bahan-bahan najis, seperti turunan hewan (kolagen) ataupun bagian dari tubuh manusia, misalnya plasenta. Kosmetik halal juga tidak boleh mengandung alkohol, karena alkohol/ Khamer tidak diperbolehkan dalam kehalalan suatu produk yang dikonsumsi. 


\section{JURNAL EKONOMI DAN MANAJEMEN \\ P-ISSN: 2598-9022/ E-ISSN: 2598-9618 \\ Available at:}

http://e-journal.unipma.ac.id/index.php/capital

Pengadaan Sertifikasi Halal pada produk pangan, obat-obatan, kosmetika dan produk lainnya sebenarnya bertujuan untuk memberikan kepastian status kehalalan suatu produk, sehingga dapat menentramkan perasaan konsumen muslim. Namun ketidak tahuan seringkali membuat minimnya perusahaan memiliki kesadaran untuk mendaftarkan diri guna memperoleh sertifikat halal. Masa berlaku sertifikat halal adalah dua tahun. Hal tersebut untuk menjaga konsistensi produksi produsen selama berlakunya sertifikat. Sedangkan untuk daging yang diekspor Surat Keterangan.

Menurut Burhanuddin (2011, h.142) alur proses pemeriksaan produk halal saat ini adalah produsen mengajukan permohonan sertifikasi dan labelisasihalal ke Badan Pengawasan Obat dan Makanan (Badan POM), kemudian Tim Audit Halal (DEPAG, LPPOM MUI dan Badan POM) melakukan audit ke lokasi. Hasil audit selanjutnya diajukan ke Tim Ahli LPPOM MUI dan diteruskan ke Komisi Fatwa MUI untuk mendapatkan sertifikat halal.

\section{Konsep kesadaran halal bagi} konsumen muslim

Menurut Randolph (2003) dalam Hasan (2016,h.3) kata "kesadaran" berarti pengetahuan atau pemahaman subjek atau situasi tertentu. Kesadaran dalam konteks Halal dapat dikonseptualisasikan sebagai proses menginformasikan untuk meningkatkan tingkat kesadaran terhadap apa yang diizinkan bagi umat Islam untuk makan, minum dan digunakan. Seperti yang dinyatakan Borzooei dan Asgari (2015). Kesadaran menjadi harapan yang disandarkan pada konsumen muslim di Indonesia. Karena dengan kesadaran konsumen yang tinggi, diharapkan akan mendorong produsen untuk lebih peduli akan produk/jasa yang halal. Dimana pada akhirnya diharapkan kehalalan menjadi hal yang mutlak bagi produsen untuk semua jenis produk yang ditujukan bagi konsumen muslim.

Kesadaran di kalangan konsumen bisa menjadi faktor penentu utama dalam proses pengambilan keputusan pembelian (Mohamed et al, 2008 dalam Hasan (2016,h.3)).Karena alasan itu, penting bagi umat Islam 


\section{JURNAL EKONOMI DAN MANAJEMEN \\ P-ISSN: 2598-9022/ E-ISSN: 2598-9618 \\ Available at:}

http://e-journal.unipma.ac.id/index.php/capital

untuk memiliki dan memahami dan mengetahui tentang halal tentang halal dalam mengukur kesadaran halal. Seperti yang disebutkan oleh Hasan (2016), Mohamed et al.,(2016), Windisukma produk halal bukan hanya bahan baku pada produk, tapi juga mencakup aspek lain seperti keselamatan dan kualitas, penanganan, peralatan pengolahan, alat bantu pengolahan, pengemasan, Penyimpanan, transporttasi, distribusi dan ritel.

Kesadaran adalah kemampuan untuk merasakan, merasakan, dan sadar akan kejadian dan objek. Ini adalah konsep tentang menyiratkan pemahaman dan persepsi terhadap kejadian atau subjek. Kesadaran telah dihipotesiskan sebagai peran penting dalam menentukan niat untuk membeli. Kesadaran halal dikonseptualisasikan untuk berkorelasi dengan niat untuk membeli.Ini menambah tingkat pengetahuan konsumen tentang makanan halal. Demikian pula, sertifikasi halal ditambahkan ke model. Penting untuk memasukkan sertifikasi/logo halal karena konsumen non Muslim dibandingkan dengan umat Islam memandangnya berbeda.Konsumen muslim mempersepsikan produk yang tersertifikasi halal ini lebih enak, higienis, dan lebih aman.

\section{Iklan (Advertising) sebagai media promosi}

Menurut Kotler \& Keller (2009:526) "advertising is any paid form of nonpersonal presentataion and promotion of ides, goods, or services by an identified sponsor", dimana terjemahan bebasnya periklanan adalah semua bentuk penyajian nonpersonal dan promosi ide, barang atau jasa yang dibayar oleh suatu sponsor tertentu. Penetapan tujuan periklanan berguna untuk memberikan pedoman bagi penyusunan keputusan pesan dan media.

Anggaran iklan yang besar bukanlah jaminan batas keberhasilan suatu kampanye iklan, karena iklan yang berhasil adalah jika iklan tersebut dapat menarik perhatian dan mengkomunikasikannya dengan baik, karena-nya, dalam merumuskan iklan, menurut Kotler \& Keller (2009:117), pemasar harus menyelesaikan empat masalah yaitu: 


\section{JURNAL EKONOMI DAN MANAJEMEN \\ P-ISSN: 2598-9022/ E-ISSN: 2598-9618 \\ Available at:}

http://e-journal.unipma.ac.id/index.php/capital
a. Isi Pesan
b. Struktur Pesan
c. Format Pesan
d. Sumber Pesan

\section{Celebrity Endroser}

Keberhasilan sebuah iklan tidak terlepas dari seorang bintang iklan (celebrity Endorser) dalam mempromosikan sebuah merek produk, terutama bila iklan tersebut ditayangkan di media televisi. Penggunaan bintang iklan dalam sebuah media televisi merupakan alternatif strategi yang tepat untuk memperkenalkan produk kepada konsumen. Pesan yang dibawakan oleh sumber yang terkenal dan menarik umumnya mampu mencuri perhatian dan recall yang lebih tinggi. Selebriti akan lebih efektif apabila mereka merupakan personafikasi atribut produk utama. Kredibilitas bintang iklan juga tak kalah pentingnya. Pesan yang disampaikan sumber yang sangat kredibel akan lebih persuasif.

Belch \& Belch (2001,h.178) mendefinisikan Endorser sebagai pendukung iklan yang ditampilkan untuk menyampaikan pesan.
Endorser sering juga disebut sebagai sumber langsung (direct source), yaitu seorang pembicara yang mengantarkan sebuah pesan dan atau memperagakan sebuah produk atau jasa. Selain itu, Endorser juga diartikan sebagai orang yang dipilih mewakili citra sebuah produk (product image), karena biasanya kalangan tokoh masyarakat memiliki karakter yang menonjol dan daya Tarik yang kuat.

Shimp (2003, 469) menggolongkan dua atribut umum dan lima atribut khusus celebrity Endorser untuk memfasilitasi efektivitas komunikasi. Secara spesifik, Shimp (2003, 470) mengatakan bahwa lima atribut khusus Endorser dijelaskan dengan akronim TEARS. Dimana TEARS tersebut terdiri dari Truthworthiness (dapat dipercaya) dan Expertise (keahlian) yang merupakan dua dimensi dari credibility; phsycal Attractiveness, Respect (kualitas dihargai) dan Similarity (kesamaan denganaudience yang dituju) merupakan komponen dari konsep umum attractiveness (daya tarik fisik). 


\section{JURNAL EKONOMI DAN MANAJEMEN \\ P-ISSN: 2598-9022/ E-ISSN: 2598-9618 \\ Available at:}

http://e-journal.unipma.ac.id/index.php/capital

\section{Teori persepsi konsumen}

Proses persepsi adalah dimana sensasi kerap diserap oleh konsumen dan digunakan untuk menafsirkan dunia sekitarnya (Solomon, etal., 2006, h.63). Tahapan proses pada proses persepsi membahas bagaimana kelima indra manusia (penglihatan, penciuman, suara, sentuhan dan rasa) mempengaruhi konsumen. Secara alamiah persepsi merupakan aktivitas pengolahan informasi (Hawkins \& Mothersbaugh, 2010, h.278). Persepsi dapat dijelaskan secara rinci merupakan serangkaian aktivitas yang menerima rangsangan/ stimuli kemudian ditransformasikan menjadi informasi, dan disimpan. Gambar 2.2 mengilustrasikan sebuah model pengolahan informasi yang berguna yang memiliki empat langkah atau tahapan utama: pemaparan, perhatian, interpretasi, dan ingatan.

Menurut Kotler \& Keller (2009, h.179) Pada kajian pemasaran bahwa persepsi lebih penting dari realitas, karena dengan persepsi konsumen akan mempengaruhi perilaku aktual konsumen. Persepsi secara singkat dapat disimpulkan proses konsumen menerjemahkan masuknya informasi dan menciptakan gambaran dunia yang lebih berarti. Poin utama pada memahami persepsi bahwa bukan hanya bergantung pada rangsangan fisik, tetapi juga pada hubungan rangsangan terhadap bidang yang mengelilinginya dan kondisi dalam setiap diri kita.

Persepsi terdiri dari aktivitas dimana seseorang memperoleh dan memberi makna pada rangsangan. Persepsi dimulai dengan Exposure. Hal ini terjadi ketika stimulus datang dalam jangkauan salah satu reseptor sensorik utama individu. Orang hanya terpapar rangsangan dalam jumlah yang kecil dan ini biasanya hasil seleksi sendiri, yang dibuktikan dengan tingginya tingkat penghindaran iklan. Attention terjadi saat rangsangan mengaktifkan satu atau lebih reseptor sensorik dan sensasi yang dihasilkan masuk ke otak untuk diproses. Orang secara selektif mendatangi rangsangan sebagai fungsi faktor stimulus, individu, dan situasional.

Faktor stimulus biasanya bersifat fisik. Karakteristik stimulus berupa kontras, ukuran, intensitas, daya tarik, warna, gerakan, posisi, isolasi, 


\section{JURNAL EKONOMI DAN MANAJEMEN \\ P-ISSN: 2598-9022/ E-ISSN: 2598-9618 \\ Available at:}

http://e-journal.unipma.ac.id/index.php/capital

format, dan kuantitas informasi.

Hemispheric lateralization adalah istilah yang diterapkan pada aktivitas yang berlangsung pada sisi otak. Sisi kiri otak terutama dipengaruhi oleh aktivitas yang biasa disebut pemikiran rasional dan kemampuan untuk sadar dan melaporkan apa yang sedang terjadi. Sisi kanan otak berhubungan dengan informasi bergambar, geometris, abadi, dan nonverbal tanpa individu dapat melaporkannya secara lisan.

Interpretation adalah penugasan makna rangsangan yang telah ada. Interpretasi cenderung bersifat relatif dan bukan absolut (relativitas perseptual) dan subjektif. Dua bentuk umum interpretasi bersifat kognitif dan afektif. Interpretasi kognitif melibatkan suatu proses dimana rangsangan baru dimasukkan ke dalam kategori makna yang ada. Penafsiran afektif adalah respon emosional atau perasaan yang dipicu oleh stimulus. Interpretasi sering kali melibatkan consumer inferences. Inferences melampaui apa yang secara langsung dinyatakan atau disajikan dan membantu menjelaskan penggunaan sinyal kualitas konsumen. Inferences juga membantu menjelaskan bagaimana konsumen dapat disesatkan oleh pesan pemasaran meskipun pesan tersebut benar.

\section{Definisi minat pembelian (purchase intention)}

Saat konsumen mengenali produk serta manfaatnya yang dapat memenuhi kebutuhan mereka, mereka akan memikirkan produk yang setidaknya dapat memenuhi kebutuhan mereka atau dapat disimpulkan konsumen berhak menyeleksi. Pada tahap timbulnya minat, konsumen menyadari mereka menyukai produk tertentu dan ingin memilikinya, hal ini dapat dikatakan timbul minat untuk membeli pada konsumen. Ketika keyakinan akan suatu produk menguat secara positif, maka akan menimbulkan keputusan untuk melakukan pembelian (Shimp, 2003, h.374). Mowen dan Minor (2002) menyatakan minat beli merupakan kecenderungan konsumen untuk membeli suatu merek atau mengambil tindakan yang berhubungan dengan pembelian yang diukur dengan 
tingkat kemungkinan konsumen melakukan pembelian.

Minat Pembelian (Purchase Intention) menurut Engel,et al (1995,h.201) dapat dikategorikan (1) berdasarkan produk atau merek dan (2) kelas produknya saja (ketika ada niat membeli es krim, tetapi tanpa ada keputusan tambahan mengenai jenis dan merek apa). Pada kategori pertama niat beli, dirujuk sebagai pembelian yang terencana sepenuhnya, sering kali merupakan hasil dari keterlibatan tinggi dan pemecahan masalah yang diperluas. Konsumen akan lebih bersedia menginvestasikan waktu dan energi dalam berbelanja dan membeli, karena itu distribusi menjadi lebih selektif.

Menurut Engel, et al (1995,h.202) dilema akan terjadi, ketika suatu pembelian tidak terencana dan niat beli disadari namun tidak diutarakan sebelum membeli. Kotler\& Keller (2009,h.165) membahasakan minat sebagai dorongan (drives), yaitu rangsangan internal yang kuat yang memotivasi tindakan, dimana dorongan ini dipengaruhi oleh stimulus dan perasaan positif akan produk. Pada tahap evaluasi, para konsumen membentuk preferensi atas merek-merek yang ada di dalam kumpulan pemilihan (Kotler \& Keller, 2009,p.166). Konsumen tersebut juga dapat membentuk niat untuk membeli merek yang paling disukai. Namun dua faktor tersebut dapat berada di antara niat pembelian dan keputusan pembelian.

Menurut Kotler \& Keller (2009, p.175) mengusulkan bahwa sikap individu dan situasi tak terduga akan mempengaruhi niat beli. Dari penjelasan di atas, dapat diketahui bahwa minat beli merupakan dorongan untuk bertindak saat konsumen mendapat stimulus, menyadari kebutuhannya, dan memiliki keyakinan akan produk. Minat beli merupakan suatu proses perencanaan pembelian suatu produk yang akan dilakukan oleh konsumen dengan mempertimbangakan beberapa hal, diantaranya adalah banyak unit produk yang dibutuhkan dalam periode waktu tertentu, merek, dan sikap konsumen dalam mengkonsumsi produk tersebut. 


\section{JURNAL EKONOMI DAN MANAJEMEN \\ P-ISSN: 2598-9022/ E-ISSN: 2598-9618 \\ Available at:}

http://e-journal.unipma.ac.id/index.php/capital

\section{METODE PENELITIAN}

Penelitian ini termasuk penelitian ekspla-natoris (explanatory research) dengan pendekatan kuantitatif, yaitu penelitian yang berupaya menjelaskan hubungan kausal antara variabelvariabel melalui pengujian hipotesis (Singarimbun dan Effendi, 1995). Pendekatan kuantitatif dilandasi pada suatu asumsi bahwa suatu gejala itu dapat diklasifikasikan, dan hubungan gejala bersifat kausal (sebab akibat) antara variabel atau konstruk melalui pengu-jian hipotesis (Sugiyono, 2010).

\begin{tabular}{llr}
\multicolumn{1}{c}{ Metode } & \multicolumn{1}{c}{ penelitian } & yang \\
digunakan & dalam & penelitian \\
menggunakan & metode survei, yaitu \\
metode yang & digunakan & untuk \\
memperoleh & informasi & melalui \\
permintaan & keterangan-keterangan \\
kepada & responden & dengan
\end{tabular}
menggunakan kuesioner sebagai alat pengumpul data utama (primer). Pada umumnya yang merupakan unit analisis dalam penelitian survei adalah individu (Singarimbun dan Effendi, 1995). Unit analisis dalam penelitian ini adalah mahasiswa Fakultas Ekonomi Universitas Muhammadiyah Ponorogo.
Populasi adalah wilayah generalisasi yang terdiri atas objek/subjek yang mempunyai kualitas dan karakteristik tertentu yang ditetapkan oleh peneliti untuk dipelajari dan kemudian ditarik kesimpulannya (Sugiyono, 2010). Populasi dalam penelitian ini adalah seluruh mahasiswa Universitas Muhammadiyah Ponorogo.

Metode pengambilan sampel yang digunakan adalah metode probability sampling. Probabilitas sampling adalah teknik pengambilan sampel yang memberi peluang atau kesempatan yang sama bagi setiap anggota populasi yang terpilih sebagai sampel penelitian (Sugiyono, 2008). Teknik pengambilan sampel yang digunakan dalam penelitian ini adalah sampel sistematis acak (systematic random sampling).yang merupakan bagian dari probability sampling. Systematic sampling meliputi menarik tiap elemen ke-n dalam populasi yang dimulai dengan elemen yang dipilih secara acak 1 dan n (Sekaran, 2006, h.128). Dalam desain pengambilan sampel sistematis acak yang dilakukan peneliti adalah dengan menggunakan generalisasi 


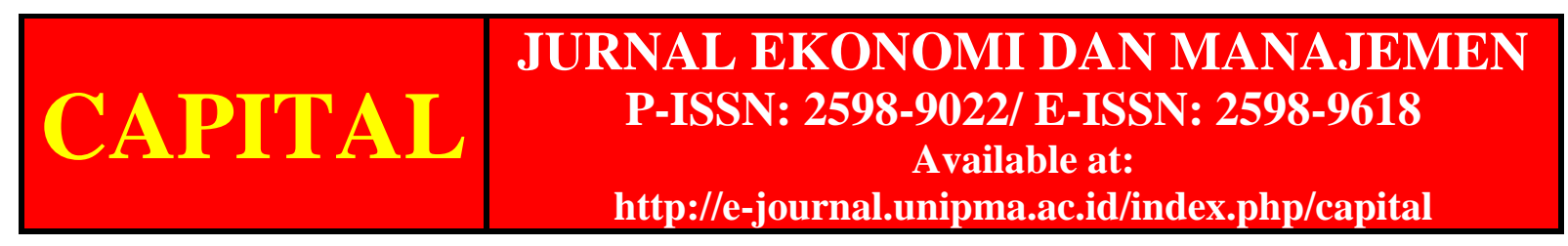

waktu, dimana peneliti dalam menyebarkan instrumen penelitian menggunakan ukuran waktu/pukul. Supaya sesuai dengan syarat sampel sistematik acak maka penyebaran kuesioner dilakukan dengan interval waktu setiap 15 menit sebagai contoh 09.15, 09.30, 09.45, 10.00 dan seterusnya

Jumlah populasi dalam penelitian ini tidak diketahui, maka untuk menentukan jumlah sampel digunakan rumus Machin and Chambell (1997; 169). Berdasarkan pertimbangan bahwa nilai terendah yang diperkirakan akan diperoleh melalui penelitian ini adalah $\mathrm{r}=0,35$; kemudian $\alpha=0,05 \quad \mathrm{Z} 1-\alpha=1,645$ pada pengukuran dua arah, dan $\beta=$ 0,10 Z1- $\beta=1,645$ maka diperoleh $n$ $($ minimum $)=100$. Sehingga dalam penelitian ini mengambil sampel minimal 100 orang responden. Dalam penelitian ini kriteria sampel adalah: Sampel merupakan konsumen kosmetik halal pada Universitas Muhammadiyah Ponorogo.

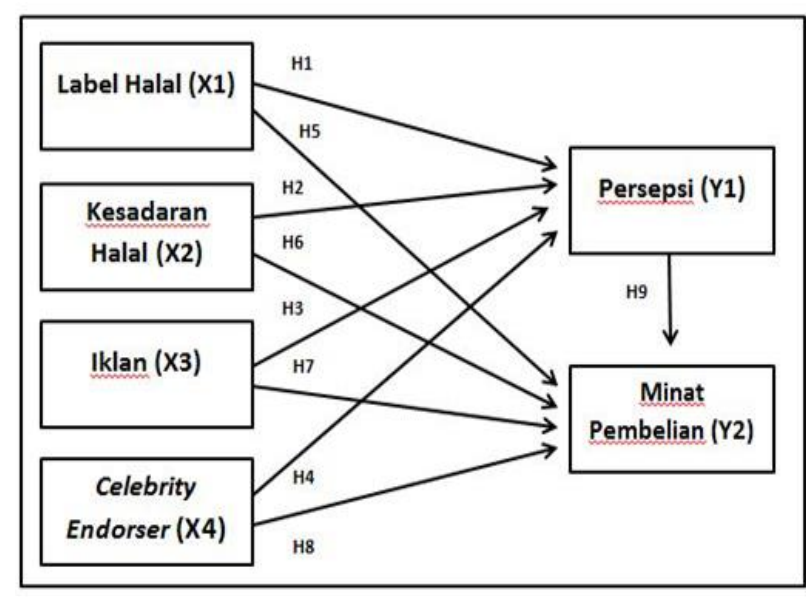

\section{Gambar 1 Model Hipotesis}

Gambar di atas menunjukkan model hipotesis dari penelitian ini. Sedangkan rumusan hipotesisnya adalah sebagai berikut:

H1: Label Halal berpengaruh positif dan signifikan terhadap Persepsi.

H2: Kesadaran Halal berpengaruh positif dan signifikan terhadap Persepsi.

H3: Iklan berpengaruh positif dan signifikan terhadap Persepsi.

H4: Celebrity Endorser berpengaruh positif dan signifikan terhadap Persepsi.

H5: Label Halal berpengaruh positif dan signifikan terhadap Minat Pembelian.

H6: Kesadaran Halal berpengaruh positif dan signifikan terhadap Minat Pembelian. 


\section{JURNAL EKONOMI DAN MANAJEMEN \\ P-ISSN: 2598-9022/ E-ISSN: 2598-9618 \\ Available at:}

http://e-journal.unipma.ac.id/index.php/capital

H7: Iklan berpengaruh positif dan signifikan terhadap Minat

Pembelian.

H8: Celebrity Endorser berpengaruh positif dan signifikan terhadap Minat Pembelian.

H9: Persepsi berpengaruh positif dan signifikan terhadap Minat Pembelian.

Metode analisis data yang digunakan untuk membuktikan hipotesis yang diajukan dalam penelitian ini menggunakan Generalized Structured Component Analysis (GSCA). GSCA dikembangkan oleh Heungsun Hwang, Hec Montreal, dan Yhoshio Takene pada 2004. Tujuannya adalah menggantikan faktor dalam kombinasi linier dari indikator (variabel manifes) di dalam analisis SEM (Solimun, 2012).Tenehaus (2008) dalam Solimun (2012) mengatakan bahwa GSCA adalah metode baru SEM berbasis komponen, sangat penting dan dapat digunakan untuk perhitungan skor (bukan skala) dan juga dapat diterapkan pada sampel yang sangat kecil. Di samping itu, GSCA dapat digunakan pada model struktural yang melibatkan variabel dengan indikator refleksif dan atau formatif.

\section{HASIL DAN PEMBAHASAN}

Responden dalam penelitian ini adalah konsumen kosmetik yang juga merupakan Civitas Akademika di Universitas Muhammadiyah Ponorogo. Total kuesioner yang disebarkan adalah 100 lembar. Adapun rincian kuesioner disajikan pada tabel di bawah ini:

Tabel 1 Distribusi dan Pengembalian Kuesioner

\begin{tabular}{|c|c|c|c|c|}
\hline \multirow{2}{*}{$\begin{array}{c}\text { Har } \\
\text { i }\end{array}$} & \multirow{2}{*}{$\begin{array}{c}\text { Jumla } \\
\mathrm{h}\end{array}$} & \multicolumn{2}{|c|}{ Kembali } & \multirow{2}{*}{$\begin{array}{l}\text { Tidak } \\
\text { Kemba } \\
\text { li }\end{array}$} \\
\hline & & $\begin{array}{l}\text { Bai } \\
\mathrm{k}\end{array}$ & $\begin{array}{l}\text { Rusa } \\
\mathrm{k}\end{array}$ & \\
\hline 1 & 14 & 14 & 0 & 0 \\
\hline 2 & 9 & 9 & 0 & 0 \\
\hline 3 & 13 & 13 & 0 & 0 \\
\hline 4 & 12 & 12 & 0 & 0 \\
\hline 5 & 15 & 15 & 0 & 0 \\
\hline 6 & 14 & 14 & 0 & 0 \\
\hline 7 & 10 & 10 & 0 & 0 \\
\hline 8 & 13 & 13 & 0 & 0 \\
\hline & 100 & \multicolumn{2}{|c|}{ Total } & 0 \\
\hline
\end{tabular}

Hasil pengujian validitas untuk item pernyataan yang digunakan dalam mengukur variabel menunjukkan nilai korelasi yang lebih besar dari nilai r-tabel yang 


\section{JURNAL EKONOMI DAN MANAJEMEN \\ P-ISSN: 2598-9022/ E-ISSN: 2598-9618 \\ Available at:}

http://e-journal.unipma.ac.id/index.php/capital

ditentukan. Dengan demikian dapat

dikatakan bahwa seluruh item pernyataan yang digunakan dalam mengukur variabel tersebut telah menunjukkan tingkat ketepatan yang cukup baik (valid). Sedangkan pengujian reliabilitas seluruh item yang digunakan dalam mengukur variabel dependent dan independent menghasilkan koefisien reliabilitas (cronbach's alpha) diatas 0.6 sehingga dapat dikatakan bahwa instrumen yang digunakan untuk mengukur seluruh variabel tersebut dinyatakan memiliki reliabilitas yang tinggi. Dengan kata lain instrumen yang digunakan tersebut telah menunjukkan konsistensi pengukuran pada semua respondennya.

Tabel 2 Model FIT GSCA

\begin{tabular}{|c|c|}
\hline \multicolumn{2}{|c|}{ Model Fit } \\
\hline FIT & 0.713 \\
\hline AFIT & 0.708 \\
\hline GFI & 0.924 \\
\hline SRMR & 0.231 \\
\hline NPAR & 100 \\
\hline
\end{tabular}

FIT menunjukkan varian total dari semua variabel yang dapat dijelaskan oleh model tertentu. Nilai FIT berkisar dari 0 sampai 1. Jadi, model yang terbentuk dapat menjelaskan semua variabel yang ada sebesar 0.713. Keragaman Label Halal, Kesadaran Halal, Iklan, Celebrity Endroser, Persepsi dan Minat Pembelian yang dapat dijelaskan oleh model adalah sebesar $71.3 \%$ dan sisanya $(28.7 \%)$ dapat dijelaskan oleh variabel yang lain. Artinya, jika dilihat dari nilai FIT yang diperoleh, model yang terbentuk dapat dikatakan bagus. Semakin besar nilai FIT yang diperoleh maka model yang ada akan semakin bagus.

Adjusted dari FIT hampir sama dengan FIT. Namun, karena variabel yang mempengaruhi Minat Pembelian tidak hanya satu sehingga akan lebih baik apabila interpretasi tentang ketepatan model menggunakan FIT yang sudah terkoreksi atau menggunakan AFIT. Karena semakin banyak variabel yang mempengaruhi maka nilai FIT semakin besar karena proporsi keragaman juga akan meningkat sehingga untuk menyesuaikan dengan variabel yang ada dapat menggunakan FIT yang sudah terkoreksi. Jika dilihat dari nilai AFIT, keragaman Label Halal, Kesadaran Halal, Iklan, Celebrity 


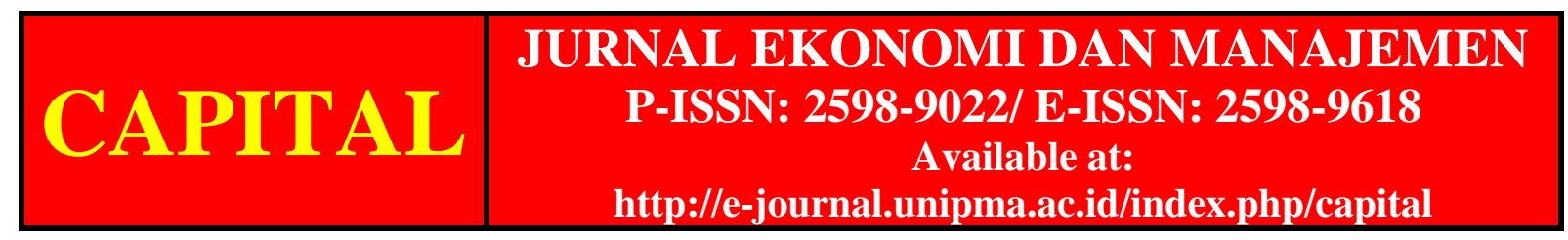

Endroser, Persepsi dan Minat

Pembelian yang dapat dijelaskan oleh model adalah sebesar $70.8 \%$ dan sisanya $(29.2 \%)$ dapat dijelaskan oleh variabel yang lain. Artinya, jika dilihat dari nilai AFIT yang diperoleh, model yang terbentuk bagus.

GFI (Unweighted least-squares) dan SRMR (standardized root mean square residual). Keduanya sebanding dengan perbedaan antara kovarian sampel dan kovarian yang diproduksi oleh pendugaan parameter GSCA. GFI dekat dengan nilai 1 dan nilai-nilai SRMR mendekati 0 dapat diambil sebagai indikasi cocok. Pada permasalahan ini nilai $\mathrm{SRMR}=0,231$ sehingga model yang terbentuk dapat dikatakan telah sesuai. Data stastistik juga menunjukkan nilai GFI $=0,924$ maka model dikatakan sesuai.

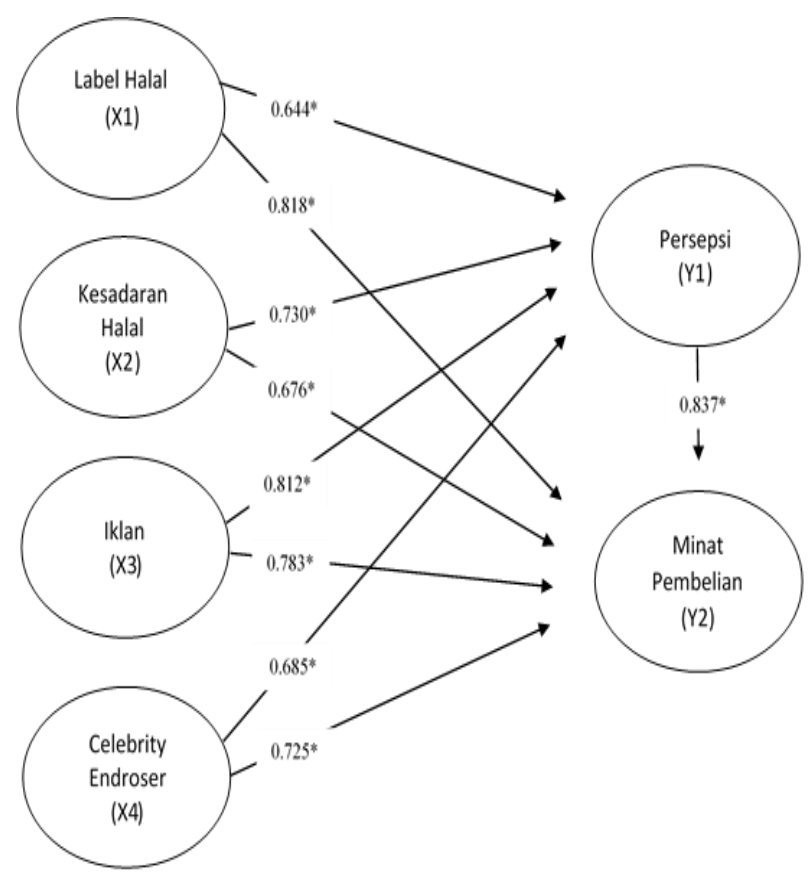

Gambar 2 Model Empiris

\section{H1 = Label Halal terhadap Persepsi.}

Hipotesis 1 menyatakan bahwa Label Halal berpengaruh signifikan terhadap Persepsi. Hasil pengujian model menggunakan GSCA menunjukkan bahwa hasil positif dan signifikan dengan nilai critical rasio sebesar 3.14 dan koefisien jalur sebesar 0.644, sehingga dapat disimpulkan bahwa Label Halal memiliki pengaruh yang signifikan dengan Persepsi. Hasil penelitian ini sejalan dengan hasil penelitian Abdul (2016) dan Flamboyant (2017). Flamboyant, et al (2017) menguji persepsi konsumen Muslim di 


\section{JURNAL EKONOMI DAN MANAJEMEN \\ P-ISSN: 2598-9022/ E-ISSN: 2598-9618 \\ Available at:}

http://e-journal.unipma.ac.id/index.php/capital

Malaysia tentang betapa pentingnya kehadiran logo halal pada kemasan makanan dan minuman ( $F$ \& $B$ ). Hasil temuan Abdul (2016) juga menunjukkan hal yang sama. Data empiris penelitian menunjukkan Label Halal berpengaruh signifikan terhadap Persepsi konsumen.

\section{H2 = Kesadaran Halal terhadap Persepsi.}

Hipotesis menyatakan bahwa Kesadaran Halal berpengaruh signifikan terhadap Persepsi. Hasil pengujian memperoleh bukti empiris bahwa $\mathrm{H} 2$ berpengaruh positif dan signifikan. Artinya, semakin tinggi Kesadaran Halal semakin tinggi pula Persepsi konsumen. Hasil pengujian model menggunakan GSCA menunjukkan bahwa hasil pengujian berpengaruh positif dan signifikan dengan nilai critial ratio sebesar 2.89 dan koefisien jalur sebesar 0.730. Hal ini konsisten dengan hasil penelitian Haslinda (2015) dan Ismael (2015).

Hasan, Haslinda (2016) dalam penelitiannya "A Study On Awareness And Perception Towards Halal Foods Among Muslim Students In Kota Kinabalu, Sabah". Studi pendahuluan mengenai perilaku agama dan konsumen, menunjukkan bahwa agama dapat mempengaruhi perilaku dan perilaku konsumen secara umum. Temuan penelitian Ismael (2015) menunjukkan bahwa niat perkotaan Generasi Y konsumen dalam mengkonsumsi makanan halal sebagian besar dipengaruhi oleh sikap, norma subjektif dan persepsi kontrol perilaku terhadap makanan halal.

\section{H3 = Iklan terhadap Persepsi.}

Hipotesis H3 menyatakan bahwa Iklan berpengaruh signifikan terhadap Persepsi. Hasil pengujian memperoleh bukti empiris bahwa $\mathrm{H} 3$ berpengaruh signifikan. Artinya, semakin tinggi Iklan semakin tinggi pula Persepsi konsumen. Hasil pengujian model menggunakan GSCA menunjukkan bahwa hasil pengujian berpengaruh signifikan dengan nilai critial ratio sebesar 2.51 dan koefisien jalur sebesar 0.812 . Hasil penelitian ini sejalan dengan hasil penelitian Lodhi (2016) dan Fatimah (2015).

Fatimah (2015) melakukan penelitian pada 200 pria muda atau 


\section{JURNAL EKONOMI DAN MANAJEMEN \\ P-ISSN: 2598-9022/ E-ISSN: 2598-9618 \\ Available at:}

http://e-journal.unipma.ac.id/index.php/capital

wanita yang menggunakan berbagai merek kosmetik untuk memeriksa pengaruh iklan terhadap perilaku pembelian mereka sambil menciptakan kesadaran dan membangun persepsi. Beberapa studi yang lain juga menunjukkan bukti empiris bahwa Iklan berpengaruh positif terhadap Persepsi. Bukti empiris ini memiliki implikasi bahwa konsumen akan cenderung melakukan pembelian apabila produsen menggunakan iklan pada waktu dan tempat yang tepat.

\section{H4 = Celebrity Endroser terhadap}

\section{Persepsi}

Hipotesis H4 menyatakan bahwa Celebrity Endroser berpengaruh signifikan terhadap Persepsi. Hasil pengujian memperoleh bukti empiris bahwa $\mathrm{H} 4$ berpengaruh positif dan signifikan. Artinya, semakin tinggi Celebrity Endroser semakin tinggi pula Persepsi konsumen. Hasil pengujian model menggunakan GSCA menunjukkan bahwa hasil pengujian berpengaruh signifikan dengan nilai critial ratio sebesar 2.18 dan koefisien jalur sebesar 0.685 . Hal ini konsisten dengan hasil penelitian
Fatimah (2015) dan Lodhi (2016). Lodhi (2015) menjelaskan selebriti tidak membuat iklan efektif namun faktor lain seperti kinerja produk, kualitas dan citra merek, kepribadian dan kepercayaan selebriti membuat pikiran konsumen memilih produk perawatan wajah tertentu dari pilihannya.

\section{H5 = Label Halal terhadap Minat} Pembelian

Hipotesis H5 menyatakan bahwa Label Halal berpengaruh signifikan terhadap Minat Pembelian. Hasil pengujian memperoleh bukti empiris bahwa $\mathrm{H} 5$ berpengaruh positif dan signifikan. Artinya, semakin tinggi Label Halal semakin tinggi pula Minat Pembelian. Hasil pengujian model menggunakan GSCA menunjukkan bahwa hasil pengujian berpengaruh signifikan dengan nilai critial ratio sebesar 2.43 dan koefisien jalur sebesar 0.818. Hal ini konsisten dengan hasil penelitian Asgari (2015) dan Abdul (2016).

Asgari (2015), meneliti “Countryof-Origin Effect on Consumer Purchase Intention of Halal Brands". Tujuan dari penelitian ini untuk 


\section{JURNAL EKONOMI DAN MANAJEMEN \\ P-ISSN: 2598-9022/ E-ISSN: 2598-9618 \\ Available at:}

http://e-journal.unipma.ac.id/index.php/capital

mengetahui secara mendalam

pengaruh merek halal terhadap minat

pembelian ditinjau dari asal negara muslim atau non muslim. Hasil penelitian juga menemukan bahwa yang utama mempengaruhi minat beli merek halal adalah rasa, harga dan kemasan.

\section{H6 = Kesadaran Halal terhadap Minat Pembelian}

Hipotesis menyatakan bahwa Kesadaran Halal berpengaruh signifikan terhadap Minat Pembelian. Hasil pengujian memperoleh bukti empiris bahwa H6 berpengaruh positif dan signifikan. Artinya, semakin tinggi Kesadaran Halal semakin tinggi pula Minat Pembelian. Hasil pengujian model menggunakan GSCA menunjukkan bahwa hasil pengujian berpengaruh signifikan dengan nilai critial ratio sebesar 3.12 dan koefisien jalur sebesar 0.676. Hal ini konsisten dengan hasil penelitian Haslinda (2016) dan Ismael (2015).

Haslinda (2016) melakukan penelitian untuk membahas tentang kesadaran siswa terhadap makanan Halal, dan sikap mereka terhadap makanan halal. Data yang digunakan dalam penelitian ini adalah data primer yang dikumpulkan dari 172 responden beragama muslim di Malaysia.

\section{H7 = Iklan terhadap Minat \\ Pembelian}

Hipotesis H7 menyatakan bahwa Iklan berpengaruh signifikan terhadap Minat Pembelian. Hasil pengujian memperoleh bukti empiris bahwa $\mathrm{H} 7$ berpengaruh positif dan signifikan. Artinya, semakin tinggi Iklan semakin tinggi pula Minat Pembelian. Hasil pengujian model menggunakan alat analisis GSCA menunjukkan bahwa hasil pengujian berpengaruh signifikan dengan nilai critial ratio sebesar 2.54 dan koefisien jalur sebesar 0.783. Hal ini konsisten dengan hasil penelitian Fatimah (2015), Asgari (2015) dan Abdul (2016).

Fatimah (2015) menunjukkan cara baru kepada para manajer untuk merancang strategi yang sesuai untuk pemasaran produk kosmetik. Kedua variabel seperti kesadaran konsumen dan persepsi konsumen akan memotivasi konsumen untuk membeli produk tertentu, karena ada hubungan 
positif yang terjalin di antara merek produk perawatan wajah yang keduanya.

digunakan di kota Karachi.

\section{H8 = Celebrity Endroser terhadap} Minat Pembelian

Hipotesis H8 menyatakan bahwa Celebrity Endroser berpengaruh signifikan terhadap Minat Pembelian. Hasil pengujian memperoleh bukti empiris bahwa $\mathrm{H} 8$ berpengaruh positif dan signifikan. Artinya, semakin tinggi Celebrity Endroser semakin tinggi pula Minat Pembelian. Hasil pengujian model menggunakan alat analisa GSCA menunjukkan bahwa hasil pengujian berpengaruh signifikan dengan nilai critial ratio sebesar 2.79 dan koefisien jalur sebesar 0.725. Hal ini konsisten dengan hasil penelitian Fatimah (2015) dan Lodhi (2016).

Lodhi, (2016) dalam penelitiaanya "Influence Of Celebrity Endorsement On Consumer Purchase Decision: A Case Of Karachi”. Tujuan utama penelitian ini adalah untuk mengetahui pengaruh selebriti yang mendukung iklan mengenai keputusan pembelian konsumen. Penelitian dilakukan pada beberapa

\section{H9 = Persepsi terhadap Minat Pembelian}

Hipotesis H9 menyatakan bahwa Persepsi berpengaruh signifikan terhadap Minat Pembelian. Hasil pengujian memperoleh bukti empiris bahwa H9 berpengaruh positif dan signifikan. Artinya, semakin tinggi Persepsi semakin tinggi pula Minat Pembelian. Hasil pengujian model menggunakan GSCA menunjukkan bahwa hasil pengujian berpengaruh signifikan dengan nilai critial ratio sebesar 3.18 dan koefisien jalur sebesar 0.837. Hal ini konsisten dengan hasil penelitian Asgari (2015), Abdul (2015), dan Lodhi (2016).

Asgari (2015) dalam penelitiannya "Country-of-Origin Effect on Consumer Purchase Intention of Halal Brands menemukan terdapat indikasi bahwa tidak ada dampak asal negara merek produk halal tersebut dalam mempengaruhi minat beli konsumen merek halal, ditemukan juga bahwa yang utama mempengaruhi minat beli 


\section{CAPITAL \\ JURNAL EKONOMI DAN MANAJEMEN \\ P-ISSN: 2598-9022/ E-ISSN: 2598-9618 \\ Available at: \\ http://e-journal.unipma.ac.id/index.php/capital}

merek halal adalah rasa, harga dan kemasan.

Tabel 3 Pengujian Structural Model

\begin{tabular}{|c|c|c|c|}
\hline \multicolumn{4}{|c|}{ Path Coefficients } \\
\hline & Estimate & SE & CR \\
\hline Label Halal-> Persepsi & 0.644 & 0.214 & $3.14 *$ \\
\hline $\begin{array}{c}\text { Kesadaran Halal-> } \\
\text { Persepsi }\end{array}$ & 0.730 & 0.257 & $2.89 *$ \\
\hline Iklan-> Persepsi & 0.812 & 0.329 & $2.51 *$ \\
\hline $\begin{array}{c}\text { Celebrity Endroser-> } \\
\text { Persepsi }\end{array}$ & 0.685 & 0.178 & $2.18 *$ \\
\hline $\begin{array}{c}\text { Label Halal-> Minat } \\
\text { Pembelian }\end{array}$ & 0.818 & 0.318 & $2.43 *$ \\
\hline $\begin{array}{c}\text { Kesadaran Halal-> Minat } \\
\text { Pembelian }\end{array}$ & 0.676 & 0.289 & $3.12 *$ \\
\hline Iklan-> Minat Pembelian & 0.783 & 0.196 & $2.54 *$ \\
\hline $\begin{array}{c}\text { Celebrity Endroser-> } \\
\text { Minat Pembelian }\end{array}$ & 0.725 & 0.322 & $2.79 *$ \\
\hline $\begin{array}{c}\text { Persepsi-> Minat } \\
\text { Pembelian }\end{array}$ & 0.837 & 0.306 & $3.18 *$ \\
\hline
\end{tabular}

\section{E. SIMPULAN}

Dari hasil penelitan dengan judul Pengaruh Label Halal, Kesadaran Halal, Iklan, dan Celebrity Endorser terhadap Minat Pembelian kosmetik melalui variabel Persepsi sebagai mediasi (Studi Pada Civitas Akademika Universitas
Muhammadiyah

Ponorogo)

menggunakan alat analisis GSCA dapat disimpulkan beberapa hal, yaitu:

1) Semua variabel yang diuji dalam model mempunyai hubungan yang positif. Dapat dikatakan bahwa jika salah satu variabel mengalami kenaikan, maka memberikan pengaruh kenaikan juga pada variabel yang lain.

2) Hasil penelitian menunjukkan bahwa penggunaan Label Halal, Kesadaran Halal, Iklan, dan Celebrity Endroser secara tepat, efektif dan efisien akan memberikan stimulus yang besar pada Persepsi konsumen dalam Minat Pembelian kosmetik.

Berdasarkan hasil penelitian, saran yang perlu dipertimbangkan yakni:

1) Peneliti selanjutnya dapat melakukan pengumpulan data dengan menggunakan penggabungan instrumen lain selain kuesioner, seperti wawancara mendalam dengan responden maupun dengan pihak penyelenggara pendidikan 


\section{JURNAL EKONOMI DAN MANAJEMEN \\ P-ISSN: 2598-9022/ E-ISSN: 2598-9618 \\ Available at:}

http://e-journal.unipma.ac.id/index.php/capital

kewirausahaan sehingga dapat

diperoleh informasi dan gambaran

variabel dan hubungannya secara

lebih jelas.

2) Berdasarkan keterbatasan pene-

litian di atas, peneliti selanjutnya disarankan untuk mengambil obyek penelitian dan jumlah sampel yang berbeda untuk mengkaji model secara lebih mendalam, serta diharapkan akan memperoleh hasil yang maksimal.

3) Bagi produsen kosmetik, disarankan untuk tetap memelihara kualitas pelayanan terhadap konsumen dengan memperhatikan segala aspek. Konsumen yang merasa puas terhadap produk kosmetik akan menjadi konsumen tetap produk itu sendiri, dan tidak akan berpindah ke produk kosmetik yang lain.

\section{DAFTAR RUJUKAN}

Aaker, David .A. 1991. Managing Brand Equity. The Free Press. New York.

Abdul, et al, (2016), "The Perception of Malaysian Consumers on the Importance of Halal Logo in Their Purchasing Decision". IOSR Journal of Humanities And
Social Science (IOSR-JHSS)

Volume 21( 10)2016. PP 08-13

Belch, George E. \& Michael A. Belch. 2001. Introduction Ad and Promotion. An Integrated Marketing. McGraw Hill Company.

Borzooei, Mahdi and Maryam Asgari, (2015), Country-ofOrigin Effect on Consumer Purchase Intention of Halal Brands, American Journal of Economics, Finance and Management, 1(2), 25-34.

Burhanuddin, (2011), Pemikiran Hukum Perlindungan Konsumen dan Sertifikat Halal, (h.140,h.142), Universitas Islam Negeri Maulana Malik Ibrahim Maliki Press. Malang.

Engel, F.J., R.D Blackwell dan P.W Miniard. 1995. Perilaku Konsumen. Terjemahan oleh F.X Budianto. Jilid 2. Binarupa Aksara. Jakarta.

Flamboyant, et al. (2017). Halal Label, Attention Ingredients, Religiosity, Counterfactual Thinking on Purchase Intention Liang Tea. International Journal of Innovative Research in Science, Engineering and Technology, Vol. 6(4) 2017

Hasan, Haslinda. (2016). A Study On Awareness And Perception Towards Halal Foods Among Muslim Students In Kota Kinabalu, Sabah., Proceedings of the Australia-Middle East Conference on Business and 


\section{JURNAL EKONOMI DAN MANAJEMEN \\ P-ISSN: 2598-9022/ E-ISSN: 2598-9618 \\ Available at:}

http://e-journal.unipma.ac.id/index.php/capital

Social Sciences 2016, Dubai (in partnership with The Journal of Developing Areas, Tennessee State University, USA).

Hawkins, I.D and D.L Mothersbaugh. 2010. Consumer behavior: building marketing strategy. 11th edition. McGraw Hill. London

Kasali, Rhenald. 1992. Manajemen Periklanan Konsep dan Aplikasinya di Indonesia. Jakarta: PT Pustaka Utama Grafiti.

Khalek and Ismail. (2015). Why Are We Eating Halal - Using the Theory of Planned Behavior in Predicting Halal Food Consumption among Generation $Y$ in Malaysia. International Journal of Social Science and Humanity, Vol. 5( 7) 2015.

Khan, Afsheen \& Samreen Lodhi, (2016). Influence Of Celebrity Endorsement On Consumer Purchase Decision: A Case Of Karachi. Imperial Journal of Interdisciplinary Research (IJIR) Vol.2(1) 2016, pp 11-19.

Kotler, Philip and Keller Kevin Lane. 2009. Principles of Marketing.. 13th Edition. Prentice Hall. New Jersey.

Levy, Miachael and B.A Weitz. 2012. Retailing Management. McGraw Hill Irwin. New York.

Momzhak, http://www.halabea.

(2015), com/2015/10/daftar-kosmetik- halal-terlengkap-2015.html, diakses 10 Mei 2016.

Pertiwi, Dewi Damayanti. 2009. Hubungan Antara Kepercayaan Diri dengan Minat Membeli Kosmetik pada Konsumen Klinik Kecantikan. Fakultas Psikologi. Universitas Muhammadiyah Surakarta. (diakses tanggal 3 Juni 2016)

Peter, J.P dan J Olson. 2000. Consumer Behavior: Perilaku Konsumen dan Strategi Pemasaran. Alih Bahasa: Damos Sihombing. Edisi Keempat. Jilid 2. Erlangga. Jakarta.

Qardhawi,Yusuf. (2007), Halal dan Haram dalam Islam, (h.5), Era Intermedia. Surakarta.

Samar Fatima \& Samreen Lodhi, (2015). "Impact of Advertisement on Buying Behaviours of the consumers: Study of Cosmetic Industry in Karachi City". International Journal of Management Sciences and Business Research, vol.4(10)2016, pp.3242.

Sekaran, Uma. 2006. Metode Penelitian untuk Bisnis. Alih Bahasa: Kwan Men Yon. Edisi ke 4, Buku 2. Penerbit Salemba Empat. Jakarta.

Shimp, Terence A. 2003. Periklanan Promosi dan Aspek Tambahan Komunikasi Pemasaran Terpadu. Edisi Ke-5, Jilid I. Alih Bahasa: Revyani Sahrial, 
Dyah Anikasari. Editor: Nurcahyo Mahanani. Jakarta: Erlangga.

Singarimbun, Masri dan Sofian Effendi. 2011. Edisi Editor. Metode Penelitian Survai. Edisi Revisi. LP3ES. Jakarta.

Solimun. 2012. Penguatan Confirmatory Reseach Pemodelan Persamaan Struktural Generalized Structured Componeny Analysis GSCA. Program Studi Statistika FMIPA Universitas Brawijaya. Malang.

Solomon, R.M, et al. 2006. Consumer Behavior; Buying Having and Being. Prentice Hill Pearson .New Jersey.

Sugiyono. 2008. Metode Penelitian Bisnis (Pendekatan Kuantitatif, Kualitatif dan $R \& D)$. Alfabeta. Bandung.

Sugiyono. 2010. Metode Penelitian Bisnis: Pendekatan Kuantitatif, Kualitatif, dan R\&D, edisi kelimabelas. Alfabeta. Bandung.

Sumarwan, Ujang. 2011. Perilaku konsumen: teori dan penerapannya dalam pemasaran. Ghalia Indonesia. Bandung.

Budiawati, Arie Dwi,. (2016), https://www. dream.co.id/dinar/merekmerek-ini-sabet-penghargaanhalal-award-2016- 161021r.html. diakses 10 Desember 2016.

Widyaningrum, Premi wahyu, 2016. Pengaruh Label Halal dan Celebrity Endorser terhadap Keputusan Pembelian (Survei pada Konsumen Wardah di Ponorogo). Jurnal Jesi vol.6 no.2. 2016.

Widyaningrum, Premi wahyu, Achmad Fauzi dan Zainul Arifin. 2013. Pengaruh Ekuitas Merek Terhadap Minat Pembelian Serta Dampaknya Terhadap Keputusan Pembelian (Survey pada Konsumen Smartphone BlackBerry Pengunjung Malang Plaza). Jurnal Profit: Vol. 7 No.2, Th 2013. 